\title{
Bemiparin Versus Enoxaparin for Extended Thromboprophylaxis in COVID-19 Patients at High Risk of Venous Thromboembolism
} COVID-19'da Tromboembolizm Profilaksisinde Bemiparin ve Enoksaparinin Karşılaştırılması

\author{
(1) Ahmet Can TOPÇU ${ }^{1}$, (1) Gözde ÖZTÜRK-ALTUNYURT ${ }^{2}$, (1) Nurdan PAPILA-TOPAL ${ }^{3}$, (1) Ayşe BATIREL ${ }^{2}$ \\ 1 University of Health Sciences Turkey, Kartal Dr. Lütfi Kırdar City Hospital, Clinic of Cardiovascular Surgery, Istanbul, Turkey \\ 2 University of Health Sciences Turkey, Kartal Dr. Lütfi Kırdar City Hospital, Clinic of Infectious Diseases and Clinical Microbiology, Istanbul, Turkey \\ 3University of Health Sciences Turkey, Kartal Dr. Lütfi Kırdar City Hospital, Clinic of Cardiology, Istanbul, Turkey
}

\section{Abstract}

Introduction: Patients with COVID-19 are at increased risk of thromboembolic events during hospitalization and after discharge. Current guidelines recommend use of extended thromboprophylaxis in hospitalized COVID-19 patients who have high risk of post-discharge venous thromboembolism and low risk of bleeding. We aimed to report our experience regarding different low-molecular-weight heparins administered post-discharge in a COVID-19 patient population with high-thromboembolic and low-bleeding risk.

Methods: This was a single-center, retrospective, observational study. Consecutive patients admitted with a confirmed diagnosis of COVID-19 between March 16 and July 16, 2020, were assessed for enrollment. Patients were included if they received prophylaxis with low-molecularweight heparins after discharge, were $\geq 18$ years of age, and completed follow-up. Pregnant women, children $<18$ years of age, patients with intensive care unit admission, and patients who experienced venous and/or arterial thromboembolism prior to discharge were excluded. Extended thromboprophylaxis with either enoxaparin 4000 IU once daily or bemiparin 3500 IU once daily was prescribed if a patient had a modified IMPROVE VTE score of $\geq 4$, or a modified IMPROVE score of $\geq 2$ and a D-dimer level of $\geq 2$ times the reference range. Patients were followed-up for 30 days after discharge. Primary endpoint was occurrence of radiologically confirmed symptomatic venous thromboembolism (deep vein thrombosis and/ or pulmonary embolism).

Results: A total of 3498 consecutive patients were hospitalized with a diagnosis of COVID-19. Of them, 38 (20 women) received extended thromboprophylaxis. Mean of age was $66.6 \pm 15.7$ years. Twenty-five patients received enoxaparin, and 13 received bemiparin. Three patients in the enoxaparin group and none of the patients in the bemiparin group experienced post-discharge venous thromboembolism ( $p=0.681$ ). Major bleeding occurred in one patient in the enoxaparin group, and in zero patients in the bemiparin group ( $p=0.456)$.

Conclusion: Enoxaparin and bemiparin have similar prophylactic properties when used for prevention of post-discharge venous thromboembolism in COVID-19 survivors who have high thromboembolic and low bleeding risk.

Keywords: Bemiparin, COVID-19, enoxaparin, extended thromboprophylaxis, low-molecular-weight heparin

Cite this article as: Topçu AC, Öztürk-Altunyurt G, Papila-Topal N, Batırel A. Bemiparin Versus Enoxaparin for Extended Thromboprophylaxis in COVID-19 Patients at High Risk of Venous Thromboembolism. Mediterr J Infect Microb Antimicrob 2021;10:65. 
Giriş: COVID-19 hastaları, hastane yatışı süresince ve taburculuk sonrasında tromboembolik hadiseler açısından artmış risk altındadır. Güncel kılavuzlar taburculuk sonrası venöz tromboembolizm riski yüksek ve kanama riski düşük olan COVID-19 hastalarında uzamış tromboprofilaksi kullanımını önermektedir. Yüksek tromboemboli ve düşük kanama riski olan bir COVID-19 hasta popülasyonunda taburculuk sonrası uygulanan farklı düşük molekül ağırlıklı heparinlere ilişkin tecrübemizi sunmayı amaçladık.

Yöntem: Bu çalışma tek merkezli, retrospektif, gözlemsel çalışma olarak tasarlandı. 16 Mart ve 16 Temmuz 2020 tarihleri arasında doğrulanmış COVıD-19 tanısıyla yatırılan ardışık hastalar çalışmaya dahil edilmek üzere değerlendirildi. Taburculuk sonrası düşük molekül ağırlıklı heparin ile profilaksi almış olan 18 yaşından büyük ve takip süresini tamamlamış hastalar çalışmaya dahil edildi. Hamileler, 18 yaşından küçükler, yoğun bakım ünitesinde takip edilen hastalar ve taburculuk öncesi venöz ve/veya arteryel tromboembolik olay yaşamış olan hastalar dışlandı. Modifiye IMPROVE VTE skoru en az 4 olan veya modifiye IMPROVE VTE skoru en az 2 olup D-dimer düzeyi üst sınırın en az 2 katı olan hastalara enoksaparin 4000 IU/ gün veya bemiparin $3500 \mathrm{IU} /$ gün ile uzamış tromboprofilaksi reçete edildi. Hastalar taburculuk sonrası 30 gün süresince takip edildi. Primer sonlanım noktası, radyolojik olarak doğrulanmış semptomatik venöz tromboembolizm (derin ven trombozu ve/veya pulmoner emboli) gelişmesiydi.

Bulgular: Toplam 3498 ardışık hasta doğrulanmış COVID-19 tanısıyla yatarak tedavi edildi. Bunlar arasından 38 hasta (20 kadın) uzamış tromboprofilaksi

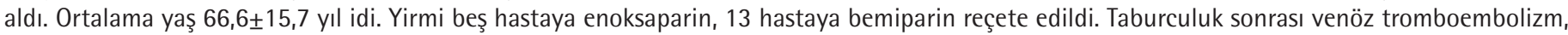
enoksaparin grubundaki hastaların üçünde görülürken, bemiparin grubundaki hastaların hiçbirinde görülmedi $(p=0,681)$. Enoksaparin grubundaki bir hastada majör kanama gelişirken, bemiparin grubundaki hastalarda majör kanama gelişmedi $(p=0,456)$.

Sonuç: COVID-19 geçiren yüksek tromboemboli ve düşük kanama riski olan hastalarda taburculuk sonrası venöz tromboembolizmin önlenmesinde enoksaparin ve bemiparinin benzer profilaktik özelliklere sahip olduğu görülmektedir.

Anahtar Kelimeler: Bemiparin, COVID-19, düşük molekül ağırlıklı heparin, enoksaparin, uzamış tromboprofilaksi

\section{Introduction}

Coronavirus disease 2019 (COVID-19) has been shown to be associated with a hypercoagulable state which manifests as venous and arterial thromboembolic events across multiple systems, with the former being more common ${ }^{[1,2]}$. Even though the underlying pathophysiology is not fully understood, it is evident that patients with COVID-19 are at increased risk of venous thromboembolism (VTE), ischemic stroke, myocardial infarction, limb ischemia and visceral ischemia during hospitalization and after discharge ${ }^{[3-9]}$. Most of the current consensus reports ${ }^{[10-14]}$ recommend against routine use of postdischarge thromboprophylaxis following hospitalization for COVID-19, and that extended prophylaxis should be restricted to selected patients who are at high risk of VTE and low risk of bleeding, whereas others ${ }^{[15]}$ advocate that extended thromboprophylaxis with low-molecular-weight heparins (LMWHs) should be considered for all hospitalized COVID-19 patients. However, there is no evidence regarding which LMWH these high-risk patients would benefit from. We aimed to report our experience regarding different LMWHs administered post-discharge in a COVID-19 patient population with highthromboembolic and low-bleeding risk.

\section{Materials and Methods}

This was a single-center, retrospective, observational study. The study protocol was approved by Institutional Research Ethics Committee which waived the need for individual informed consent (reference: 2020/514/182/2). Study procedures were conducted in accordance with ethical standards of the World
Medical Association's Declaration of Helsinki. Consecutive patients admitted to Department of Infectious Diseases at Kartal Dr. Lutfi Kirdar City Hospital with a confirmed diagnosis of COVID-19 between March 16 and July 16, 2020, were retrospectively assessed for possible enrollment. Patients were included if they received prophylaxis with LMWH after discharge, were $\geq 18$ years of age, and completed follow-up. Pregnant women, children $<18$ years of age, patients with intensive care unit admission, and patients who experienced venous and/or arterial thromboembolism prior to discharge were excluded. Patient demographics, co-morbidities, clinical variables, and biochemical markers were noted. Data was collected via patient charts and follow-up visit notes. All patients received subcutaneous (s.c.) enoxaparin during hospitalization. Extended thromboprophylaxis was used if a patient had a modified IMPROVE VTE score of $\geq 4$, or a modified IMPROVE score of $\geq 2$ and a D-dimer level of $\geq 2$ times the reference range ${ }^{[16]}$. Either enoxaparin 4000 IU once daily s.c. or bemiparin 3500 IU once daily s.c. was prescribed based on physician preference.

Patients were followed-up for 30 days after discharge. Primary endpoint was occurrence of radiologically confirmed symptomatic VTE (deep vein thrombosis [DVT] and/or pulmonary embolism [PE]). Secondary endpoints were occurrence of ischemic stroke, myocardial infarction, acute limb ischemia, composite thromboembolism (venous and/or arterial), and major bleeding as previously defined by others ${ }^{[17]}$.

\section{Statistical Analysis}

IBM SPSS Statistics for Windows version 20.0 (IBM Corp., Armonk, N.Y., USA) was used for all statistical analyses. Categorical 
variables were presented as frequencies and proportions. Distribution of numerical data was assessed by Shapiro-Wilk normality test. Variables with normal distribution were presented as mean \pm standard deviation (SD), and those with non-normal distribution were presented as median (minimum-maximum). Categorical variables were analyzed using chi-square test, and numerical variables were analyzed using Student's t-test. A twosided $p$ value of $<0.05$ was considered statistically significant.

\section{Results}

A total of 3498 consecutive patients were hospitalized with a diagnosis of COVID-19 confirmed by reverse transcriptase polymerase chain reaction test within the study period. Of them, 38 (20 women) received extended thromboprophylaxis with LMWH and were included in the study (Figure 1). Mean of age was $66.6 \pm 15.7$ years. Study population spent a median (min-max) of five (2-21) days in hospital. Following discharge, 25 patients received enoxaparin, and 13 received bemiparin (Figure 1). Groups were balanced in terms of demographics, comorbidities and laboratory markers (Table 1).

Three patients in the enoxaparin group experienced VTE (two PE and one DVT-PE) after discharge, whereas none of the patients in the bemiparin group experienced VTE $(p=0.681)$. None of the patients with VTE had hereditary thrombophilia. Major bleeding occurred in one patient in the enoxaparin group, and in zero patients in the bemiparin group $(p=0.456)$. Also, there was no statistically significant difference between the groups regarding stroke, myocardial infarction, acute limb ischemia and composite thromboembolic events (Table 2).

\section{Discussion}

The results of the present work indicate that enoxaparin and bemiparin have similar prophylactic properties when used for prevention of post-discharge VTE in COVID-19 survivors who have high thromboembolic and low bleeding risk. While this is the first study to compare different LMWHs in a COVID-19 patient population, our primary findings correlate with results from previous research performed on postpartum women ${ }^{[18]}$, and patients undergoing plastic and reconstructive procedures ${ }^{[19]}$, and orthopedic surgery ${ }^{[20]}$. Conversely, a recent randomized controlled trial[21] revealed that bemiparin was superior to enoxaparin as a prophylactic agent for VTE in critically ill patients. Of note, this randomized trial was performed in an intensive care unit setting, and thromboprophylaxis was not extended in the post-discharge period ${ }^{[21]}$. It was also previously reported that bemiparin was more cost-effective than enoxaparin for extended VTE prophylaxis after orthopedic surgery ${ }^{[22,23]}$. Costeffectiveness was not a research question of our study.

There is a lack of high-level evidence in the current medical literature with regards to use of extended post-discharge

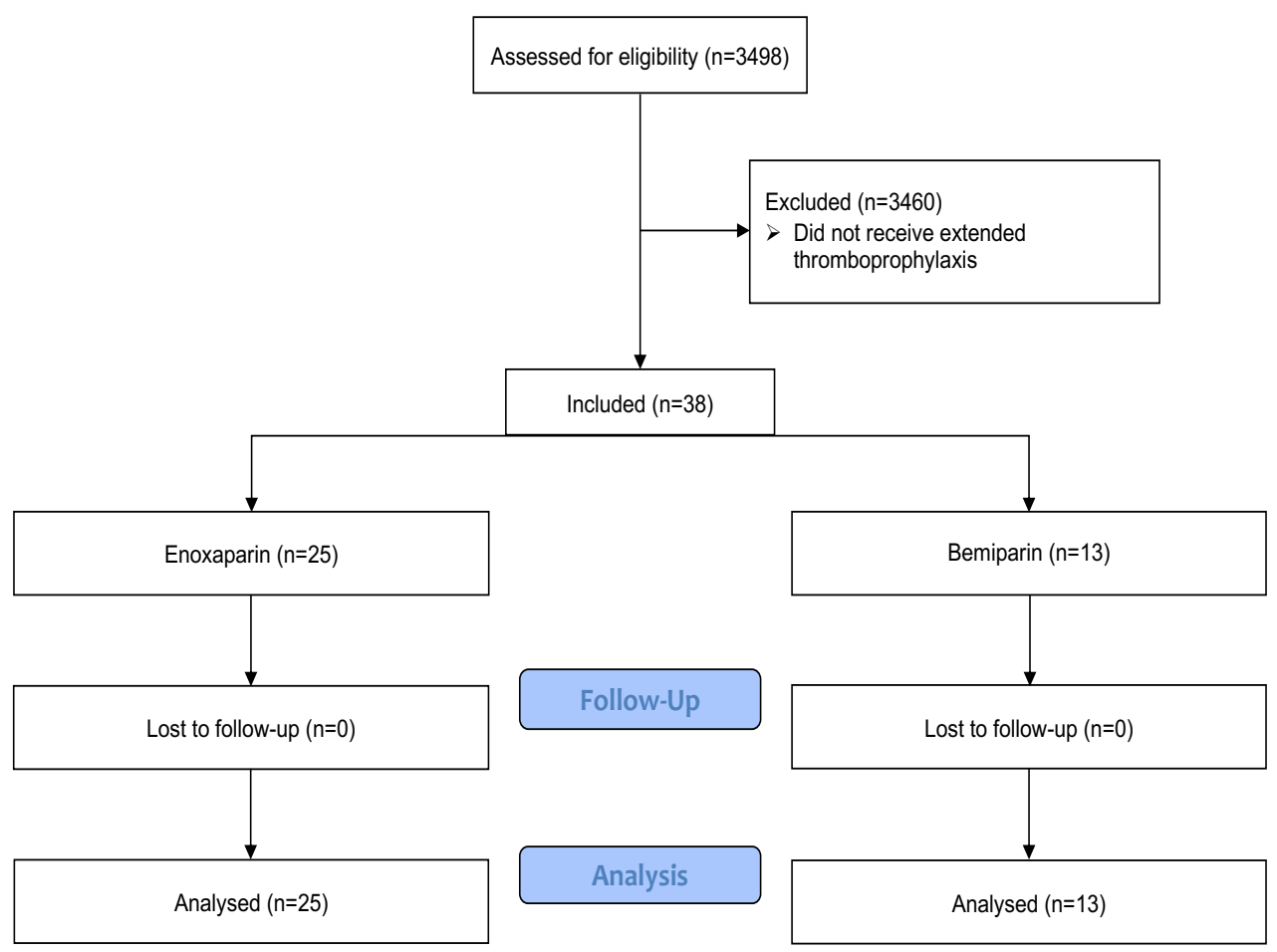

Figure 1. Flow diagram of the study population 
Table 1. Patient demographics, comorbidities, and clinical features

\begin{tabular}{|c|c|c|c|}
\hline & Enoxaparin $(n=25)$ & Bemiparin $(n=13)$ & $p$ value \\
\hline Male sex, n (\%) & $13(72.2)$ & $5(27.8)$ & 0.428 \\
\hline Age (years), mean $\pm S D$ & $66.9 \pm 15.5$ & $65.9 \pm 16.7$ & 0.839 \\
\hline Height $(\mathrm{cm})$, mean \pm SD & $166.4 \pm 1.4$ & $166.6 \pm 4.2$ & 0.955 \\
\hline Weight $(\mathrm{kg})$, mean $_{ \pm} \mathrm{SD}$ & $74.8 \pm 0$ & $73 \pm 2.1$ & 0.706 \\
\hline $\mathrm{BMI}\left(\mathrm{kg} / \mathrm{m}^{2}\right)$, mean $\pm \mathrm{SD}$ & $26.9 \pm 0.5$ & $26.4 \pm 2.3$ & 0.732 \\
\hline Comorbidities, n (\%) & $18(72)$ & $7(28)$ & 0.263 \\
\hline Active malignancy & $3(75)$ & $1(25)$ & 0.681 \\
\hline Hypertension & $15(71.4)$ & $6(28.6)$ & 0.415 \\
\hline Diabetes mellitus & $11(64.7)$ & $6(35.3)$ & 0.899 \\
\hline $\begin{array}{l}\text { D-dimer level }(\mathrm{ng} / \mathrm{ml}), \text { mean } \pm \text { SD } \\
\text { On hospital admission } \\
\text { On discharge } \\
\text { Outpatient follow-up }\end{array}$ & $\begin{array}{l}1660.8 \pm 1914 \\
1509.6 \pm 1620.7 \\
1260 \pm 917.5\end{array}$ & $\begin{array}{l}1363.1 \pm 1024 \\
2835.83 \pm 2851.7 \\
692.8 \pm 551.2\end{array}$ & $\begin{array}{l}0.606 \\
0.079 \\
0.35\end{array}$ \\
\hline Length of hospital stay (days), mean \pm SD & $7.12 \pm 4.7$ & $5.31 \pm 2.3$ & 0.204 \\
\hline
\end{tabular}

BMI: Body mass index, SD: Standard deviation

Table 2. Postdischarge outcomes

\begin{tabular}{lll}
\hline & Enoxaparin $(\mathbf{n = 2 5})$ & Bemiparin (n=13) \\
\hline Venous thromboembolism, $\mathrm{n}(\%)$ & $3(100)$ & 0 \\
\hline Pulmonary embolism, $\mathrm{n}(\%)$ & $3(100)$ & 0 \\
\hline Ischemic stroke, $\mathrm{n}(\%)$ & $1(100)$ & 0 \\
\hline Acute myocardial infarction, $\mathrm{n}(\%)$ & $1(50)$ & $1(50)$ \\
\hline Acute limb ischemia, $\mathrm{n}(\%)$ & 0 & 0 \\
\hline Composite thromboembolism, $\mathrm{n}(\%)$ & 0 & 0 \\
\hline Major bleeding, $\mathrm{n}(\%)$ & $3(75)$ & $1(25)$ \\
\hline Mortality, $\mathrm{n}(\%)$ & $1(100)$ & 0 \\
\hline
\end{tabular}

thromboprophylaxis in COVID-19 survivors. Current guidelines $^{[10-15]}$ derive their recommendations from previous experience with medically ill populations and not COVID-19 patients. To date, no randomized clinical trials have been published about this topic. Most studies are observational in design, and report low incidence of VTE in COVID-19 patients after discharge ${ }^{[8,9,24]}$. ACTIV-4c (COVID-19 Thrombosis Prevention Trials: Post-hospital Thromboprophylaxis; NCT04650087) and MICHELLE (Medically III Hospitalized Patients for COVID-19 THrombosis Extended ProphyLaxis With Rivaroxaban ThErapy: The MICHELLE Trial; NCT04662684) trials are still ongoing and their results will be of significant importance ${ }^{[25]}$. We administered extended thromboprophylaxis at time of discharge if a given patient was deemed to have a high risk of thromboembolism and low risk of bleeding.

There was also no significant difference between the groups regarding arterial thromboembolic events after discharge. Based on preliminary experience with arterial thromboembolism during the current pandemic, we already know that hospitalized COVID-19 patients are at increased risk of stroke, myocardial infarction, limb and splanchnic ischemia, and that low dose LMWHs are usually inadequate to prevent these devastating complications ${ }^{[1,5,6]}$. However, pathophysiology of arterial ischemia associated with COVID-19 is different from pathophysiology of classical arterial ischemia. Whereas classical arterial thromboembolism mainly results from disruption of atherosclerotic plaques or embolization from proximal sources such as cardiac chambers or arterial aneurysms, there are several reports about ischemic events caused by in-situ thrombosis of relatively healthy arteries observed during the course of COVID-19 infection ${ }^{[6,26-29]}$. Whether extended thromboprophylaxis with LMWHs is of benefit to COVID-19 patients concerning arterial thromboembolic events remains unclear. Our study does not answer that question due to absence of a control group consisting of patients who had similar risk profile without extended thromboprophylaxis. 
There are several limitations to the present study. The sample size was relatively small. Radiological imaging was only performed in case of symptoms suggestive of VTE, therefore asymptomatic case may have been missed. There was no control group of patients with high risk of VTE and low risk of bleeding who did not receive thromboprophylaxis.

\section{Conclusion}

Enoxaparin and bemiparin seem to have similar prophylactic properties when used for prevention of post-discharge VTE in COVID-19 survivors who have high thromboembolic and low bleeding risk. More research is warranted to reveal efficacy and safety of different anticoagulant drugs in this delicate patient population.

\section{Ethics}

Ethics Committee Approval: The study were approved by the Kartal Dr. Lütfi Kırdar City Hospital, Institutional Research Ethics Committee (reference: 2020/514/182/2, date: 22.07.2020).

Informed Consent: Retrospective study.

Peer-review: Externally peer-reviewed.

\section{Authorship Contributions}

Surgical and Medical Practices: A.C.T., G.Ö-A., N.P-T., A.B., Concept: A.C.T., G.Ö-A., N.P-T., A.B., Design: A.C.T., G.Ö-A., N.P-T., A.B., Data Collection or Processing: A.C.T., G.Ö-A., N.P-T., A.B., Analysis or Interpretation: A.C.T., G.Ö-A., N.P-T., A.B., Literature Search: A.C.T., G.Ö-A., N.P-T., A.B., Writing: A.C.T., G.Ö-A., N.P-T., A.B.

Conflict of Interest: No conflict of interest was declared by the authors.

Financial Disclosure: The authors declared that this study received no financial support.

\section{References}

1. Malas MB, Naazie IN, Elsayed N, Mathlouthi A, Marmor R, Clary B. Thromboembolism risk of COVID-19 is high and associated with a higher risk of mortality: A systematic review and meta-analysis. EClinicalMedicine. 2020;29:100639.

2. Porfidia A, Valeriani E, Pola R, Porreca E, Rutjes AWS, Di Nisio M. Venous thromboembolism in patients with COVID-19: Systematic review and metaanalysis. Thromb Res. 2020;196:67-74.

3. Loo J, Spittle DA, Newnham M. COVID-19, immunothrombosis and venous thromboembolism: biological mechanisms. Thorax. 2021;76:412-20.

4. Tan BK, Mainbourg S, Friggeri A, Bertoletti L, Douplat M, Dargaud Y, Grange $\mathrm{C}$, Lobbes $\mathrm{H}$, Provencher $\mathrm{S}$, Lega JC. Arterial and venous thromboembolism in COVID-19: a study-level meta-analysis. Thorax 2021;76:970-9.

5. Cheruiyot I, Kipkorir V, Ngure B, Misiani M, Munguti J, Ogeng'o J. Arterial thrombosis in coronavirus disease 2019 patients: a rapid systematic review. Ann Vasc Surg. 2021;70:273-81.
6. Topcu AC, Ozturk-Altunyurt G, Akman D, Batirel A, Demirhan R. Acute Limb Ischemia in Hospitalized COVID-19 Patients. Ann Vasc Surg 2021;74:88-94.

7. Bilaloglu $S$, Aphinyanaphongs $Y$, Jones $S$, Iturrate $E$, Hochman J, Berger JS. Thrombosis in Hospitalized Patients With COVID-19 in a New York City Health System. JAMA. 2020;324:799-801.

8. Roberts LN, Whyte MB, Georgiou L, Giron G, Czuprynska J, Rea C, Vadher B, Patel RK, Gee E, Arya R. Postdischarge venous thromboembolism following hospital admission with COVID-19. Blood. 2020;136:1347-50.

9. Patell R, Bogue T, Koshy A, Bindal P, Merrill M, Aird WC, Bauer KA, Zwicker JI. Postdischarge thrombosis and hemorrhage in patients with COVID-19. Blood. 2020;136:1342-6.

10. COVID-19 Treatment Guidelines Panel. Coronavirus Disease 2019 (COVID-19) Treatment Guidelines. National Institutes of Health. Last Accessed Date: 23.05.2021. Available from: https://www.covid19treatmentguidelines.nih. gov/

11. Moores LK, Tritschler $T$, Brosnahan $S$, Carrier $M$, Collen JF, Doerschug K, Holley AB, Jimenez D, Le Gal G, Rali P, Wells P. Prevention, diagnosis, and treatment of VTE in patients with coronavirus disease 2019: CHEST guideline and expert panel report. Chest. 2020;158:1143-63.

12. Bikdeli B, Madhavan MV, Jimenez D, Chuich $T$, Dreyfus I, Driggin $E_{1}$ Nigoghossian C, Ageno W, Madjid M, Guo Y, Tang LV, Hu Y, Giri J, Cushman M, Quéré I, Dimakakos EP, Gibson CM, Lippi G, Favaloro EJ, Fareed J, Caprini $J A$, Tafur AJ, Burton JR, Francese DP, Wang EY, Falanga A, McLintock C, Hunt BJ, Spyropoulos AC, Barnes GD, Eikelboom JW, Weinberg I, Schulman S, Carrier M, Piazza G, Beckman JA, Steg PG, Stone GW, Rosenkranz S, Goldhaber SZ, Parikh SA, Monreal M, Krumholz HM, Konstantinides SV, Weitz JI, Lip GYH; Global COVID-19 Thrombosis Collaborative Group, Endorsed by the ISTH, NATF, ESVM, and the IUA, Supported by the ESC Working Group on Pulmonary Circulation and Right Ventricular Function. COVID-19 and Thrombotic or Thromboembolic Disease: Implications for Prevention, Antithrombotic Therapy, and Follow-Up: JACC State-of-the-Art Review. J Am Coll Cardiol. 2020;75:2950-73.

13. Spyropoulos AC, Levy JH, Ageno W, Connors JM, Hunt BJ, Iba T, Levi M, Samama CM, Thachil J, Giannis D, Douketis JD; Subcommittee on Perioperative, Critical Care Thrombosis, Haemostasis of the Scientific, Standardization Committee of the International Society on Thrombosis and Haemostasis. Scientific and Standardization Committee communication: Clinical guidance on the diagnosis, prevention, and treatment of venous thromboembolism in hospitalized patients with COVID-19. J Thromb Haemost. 2020;18:1859-65.

14. Barnes DG, Burnett $A$, Allen $A$, Blumenstein $M$, Clark NP, Cuker $A$, Dager WE, Deitelzweig SB, Ellsworth S, Garcia D, Kaatz S, Minichiello T. Thromboembolism and anticoagulant therapy during the COVID-19 pandemic: interim clinical guidance from the anticoagulation forum. J Thromb Thrombolysis. 2020;50:72-81.

15. Marietta M, Ageno W, Artoni A, De Candia E, Gresele P, Marchetti M, Marcucci R, Tripodi A. COVID-19 and haemostasis: a position paper from Italian Society on Thrombosis and Haemostasis (SISET). Blood Transfus. 2020;18:167-9.

16. Spyropoulos AC, Lipardi C, Xu J, Peluso C, Spiro TE, De Sanctis Y, Barnathan ES, Raskob GE. Modified IMPROVE VTE risk score and elevated D-dimer Identify a high venous thromboembolism risk in acutely III medical population for extended Thromboprophylaxis. TH Open. 2020;4:e59-65.

17. Roskell NS, Samuel M, Noack H, Monz BU. Major bleeding in patients with atrial fibrillation receiving vitamin $\mathrm{K}$ antagonists: a systematic review of randomized and observational studies. Europace. 2013;15:787-97.

18. Alalaf SK, Jawad RK, Muhammad PR, Ali MS, Al Tawil NG. Bemiparin versus enoxaparin as thromboprophylaxis following vaginal and abdominal deliveries: a prospective clinical trial. BMC Pregnancy Childbirth. 2015;15:72. 
19. Revilla-Penazola F, Olsoff-Pagovich PJ, Ochoa-Gomez JR, Castaneda-Gaxiola R, Rubiyo-Gayosso Al, Ceballos G, Molina-Guarneros JA. Randomized trial of deep vein thrombosis chemoprophylaxis with bemiparin and enoxaparin in patients with moderate to high thrombogenic risk undergoing plastic and reconstructive surgery procedures. Aesthetic Plast Surg. 2020;44:820-9.

20. Navarro-Quilis $A$, Castellet $E$, Rocha $E$, Paz-Jiménez J, Planès $A$; Bemiparin Study Group in Knee Arthroplasty. Efficacy and safety of bemiparin compared with enoxaparin in the prevention of venous thromboembolism after total knee arthroplasty: a randomized, double-blind clinical trial. J Thromb Haemost. 2003;1:425-32.

21. Abbas MS. Bemiparin versus enoxaparin in the prevention of venous thromboembolism among intensive care unit patients. Indian J Crit Care Med. 2017;21:419-23.

22. Honorato J, Gómez-Outes A, Navarro-Quilis A, Martínez-González J, Rocha $E$, Planès $A$. Pharmacoeconomic analysis of bemiparin and enoxaparin as prophylaxis for venous thromboembolism in total knee replacement surgery. Pharmacoeconomics. 2004;22:885-94.

23. Gómez-Outes $A$, Berto $P$, Prandoni P. Cost-effectiveness of bemiparin in the prevention and treatment of venous thromboembolism. Expert Rev Pharmacoecon Outcomes Res. 2006;6:249-59.

24. Rashidi F, Barco S, Kamangar F, Heresi GA, Emadi A, Kaymaz C, Jansa P, Reis A, Rashidi A, Taghizadieh A, Rezaeifar P, Moghimi M, Ghodrati S, Mozafari A, Foumani AA, Tahamtan O, Rafiee E, Abbaspour Z, Khodadadi K, Alamdari G, Boodaghi Y, Rezaei M, Muhammadi MJ, Abbasi M, Movaseghi F, Koohi A,
Shakourzad L, Ebrahimi F, Radvar S, Amoozadeh M, Fereidooni F, Naseari $\mathrm{H}$, Movalled K, Ghorbani $\mathrm{O}$, Ansarin K. Incidence of symptomatic venous thromboembolism following hospitalization for coronavirus disease 2019: prospective results from a multi-center study. Thromb Res. 2021;198:135-8.

25. Talasaz AH, Sadeghipour P, Kakavand H, Aghakouchakzadeh M, KordzadehKermani E, Van Tassell BW, Gheymati A, Ariannejad H, Hosseini SH, Jamalkhani S, Sholzberg M, Monreal M, Jimenez D, Piazza G, Parikh SA, Kirtane AJ, Eikelboom JW, Connors JM, Hunt BJ, Konstantinides SV, Cushman M, Weitz JI, Stone GW, Krumholz HM, Lip GYH, Goldhaber SZ, Bikdeli B. Recent randomized trials of antithrombotic therapy for patients with COVID-19: JACC state-of-the-art review. J Am Coll Cardiol. 2021;77:1903-21.

26. de Roquetaillade $C$, Chousterman $B G$, Tomasoni $D$, Zeitouni $M$, Houdart $E_{\text {, }}$ Guedon A, Reiner P, Bordier R, Gayat E, Montalescot G, Metra M, Mebazaa A. Unusual arterial thrombotic events in Covid-19 patients. Int J Cardiol. 2021;323:281-4.

27. Indes JE, Koleilat I, Hatch AN, Choinski K, Jones DB, Aldailami H, Billett $H$, Denesopolis JM, Lipsitz E. Early experience with arterial thromboembolic complications in patients with COVID-19. J Vasc Surg. 2021;73:381-9.e1.

28. Topcu AC, Ariturk C, Yilmaz E. Acute limb ischemia in a COVID-19 patient. Thrombosis Update 2021;2:100031.

29. Gomez-Arbelaez D, Ibarra-Sanchez G, Garcia-Gutierrez A, ComangesYeboles A, Ansuategui-Vicente M, Gonzalez-Fajardo JA. COVID-19-Related Aortic Thrombosis: A Report of Four Cases. Ann Vasc Surg. 2020;67:10-3. 